\title{
PENINGKATAN PERBENDAHARAAN KATA MENGGUNAKAN MEDIA WEBSITE GOOGLE IMAGE PADA ANAK TUNARUNGU KELAS XI DI SMALB-BCD YPAC JEMBER
}

\author{
Muhammad Slamet \\ SMALB - BCD YPAC Jember \\ muhammadslametrasamala@gmail.com
}

\begin{abstract}
Abstrak
Penelitian ini bertujuan untuk meningkatkan perbendaharaan kata menggunakan media website google image pada anak tunarungu kelas XI di SMALB-BCD YPAC Jember. Rancangan penelitian menggunakan penelitian tindakan kelas (Classroom Action Reseach ) yang dilaksanakan dalam 2 siklus dengan alokasi waktu 60 menit setiap kali pertemuan. Metode pengumpulan data menggunakan metode observasi dan tes. Sedangkan instrumen penelitiannya adalah lembar observasi, kegiatan belajar mengajar dan lembar kerja siswa, data yang diperoleh dianalis secara deskriptif kualitatif dan deskriptif kuantitatif. Hasil penelitian menunjukkan bahwa perbendaharaan kata dengan menggunakan media website google image pada siswa tunarungu kelas XI di SMALB-BCD YPAC Jember pada siklus I mencapai rata-rata kelas $62.3 \%$, pada siklus II rerata kelas mencapai $71.2 \%$ mengalami peningkatan sebesar $8.9 \%$. Sehingga penggunaan media website google image dapat meningkatkan pemahaman perbendaharaan kata anak tunarungu kelas XI di SMALBBCD YPAC Jember.
\end{abstract}

Kata kunci : Perbendaharaan kata, aplikasi google image, anak tunarungu

PENDAHULUAN

Keterbatasan komunikasi menjadi

permasalahan utama yang dialami anak tunarungu. Anak tunarungu kesulitan dalam memahami kata-kata dari lawan bicaranya. Buku Petunjuk Sekolah Luar Biasa (1982:21), disebutkan bahwa "Anak tunarungu 
adalah mereka yang mengalami hambatan atau gangguan fungsi pendengaran, sehingga anak atau penderita tersebut mengalami hambatan dalam perkembangan bicara, bahkan pada penderita yang berat atau serius akan menjadi bisu sama sekali". Menurut pendapat Soewito dalam Sardjono (2000:9), “Anak tunarungu adalah seseorang yang mengalami ketulian berat sampai total, yang tidak dapat lagi menangkap tutur kata tanpa membaca bibir lawan bicaranya" Hal yang demikian ini membuat anak tunarungu menjadi tertutup, tidak percaya diri dan tidak mau bersosialisasi dengan orang lain. Perbendaharaan kata bagi seorang anak sangat penting, tidak terkecuali juga untuk anak tunarungu. Anak tuna rungu wicara, dengan keterbatasan perbendaharaan kata yang dimiliki, menjadikan mereka tidak mampu mengungkapkan isi pikiran dan perasaan dalam bentuk lisan ataupun tulisan. Menurut Burhan Nurgiyantoro (1988:196) kosakata adalah perbendaharaan kata atau disebut juga leksikon yaitu adalah kekayaan kata yang dimiliki atau yang terdapat dalam suatu bahasa. Sedangkan menurut Husain Junus, dkk (1996:65) berpendapat bahwa kosakata adalah perbendaharaan kata. Perkembangan perbendaharaan kata anak tuna rungu yang baik, akan membuat mereka menjadi lebih terampil daalam berkomunikasi yaitu tidak hanya dengan sesma komunitasnya aka tetapi dengan semua orang yang ada di sekitarnya. Selain itu perbendaharaan kata yang baik akan dapat meningkatkan kemampuan komunikasi anak dan taraf konseptual anak tuna rungu.

Saat ini banyak jenis media yang dapat digunakan untuk meningkatkan kemampuan siswa. Perlunya memilih media yang menarik yang digunakan dalam proses pembelajaran. Seiring dengan perkembangan ilmu pengetahuan dan tekhnologi, internet merupakan salah satu akses mudah yang dapat dijangkau dan digunakan dalam pembelajaran. Salah satu aplikasi website internet yaitu Google Images. Google Images adalah layanan 
pencarian yang dibuat oleh Google dan diperkenalkan pada bulan juli 2001. Layanan ini memungkinkan pengguna mencari konten gambar di web. Kata kunci pencarian gambar didasarkan pada nama berkas gambar, teks tautan yang mengacu ke gambar, dan teks di dekat gambar. Saat mencari gambar, miniatur gambar yang cocok dengan kueri pencarian tersebut akan ditampilkan. Ketika pengguna mengklik miniatur tersebut, gambar tersebut ditampilkan di dalam kotak yang menimpa situs web sumbernya. Pengguna kemudian bisa menutup kotak dan menelusuri situs tersebut atau melihat gambar dalam ukuran penuh.

https://id.wikipedia.org/wiki/Google_I mages.

Di Indonesia, google adalah website yang paling banyak mudah dan banyak digunakan untuk mencari informasi melalui jaringan internet. Jumlah pengguna internet yang semakin banyak dan penggunaan internet yang sudah membudaya tidak terkecuali pada anak tunarungu. Perkembangan tekhnologi yang pesat berpengaruh besar pada perkembangan ilmu pengetahuan. Salah satu menu yang terdapat pada google adalah google image yang berfungsi untuk mencari gambar dengan mengetik kata yang terdapat dibawa kata google search.

Berdasarkan permasalahan yang ditemukan di kelas adalah sulitnya anak tunarungu dalam memahami kata-kata yang disampaikan guru dalam proses belajar mengajar. Hal tersebut menjadikan ketercapaian tujuan pembelajaran menjadi terganggu. Hambatan dalam berbahasa merupakan permasalahan utama bagi anak tunarungu. Siswa sulit menerima pembelajaran dalam bentuk komunikasi verbal, maka peneliti ingin melakukan peningkatan perbendaharaan kata dengan media yang menarik yaitu aplikasi website google image. Maka tujuan penelitian yang akan dicapai, adalah mendeskripsikan peningkatan perbendaharaan kata menggunakan website google image pada anak tunarungu kelas XI di SMALB-BCD YPAC Jember. 


\section{METODE}

Jenis penelitian yang digunakan yaitu penelitian tindakan kelas (classroom research). Pendekatan penelitian yang dilakukan adalah pendekatan kuantitatif dan kualitatif. Subyek penelitian adalah anak tunarungu kelas XI SMALB-BCD YPAC Jember. Siklus yang dilakukan sebanyak dua kali yaitu siklus I dan siklus II. Tahapantahapan kegiatan dalam penelitian. 1) Tahapan Perencanaan Tindakan, dan 2) Tahapan Observasi dan Pelaksanaan. Beberapa tahapan yang dilakukan dalam pengembangan instrumen ini ditempuh melalui lembar observasi kegiatan belajar mengajar dan Instrumen Tes.

Metode analisis data yang digunakan adalah model alur yaitu: 1) Reduksi data yaitu kegiatan penyederhanaan data yang dilakukan melalui seleksi, pengelompokan, pengorganisasian data mentah menjadi sebuah informasi, 2) Penyajian data merupakan suatu upaya menampilkan data secara jelas dan mudah dipahami dalam bentuk tabel atau perwujudan lainnya, 3) Penafsiran kesimpulan dilakukan berdasarkan data yang telah disajikan dan merupakan pengungkapan akhir dari hasil setiap tindakan, 4) Verifikasi hasil kesimpulan, merupakan kegiatan menguji kebenaran, kekokohan dan makna-makna dari data penelitian

\section{HASIL DAN PEMBAHASAN}

\section{Siklus : I}

Hasil pengamatan di lapangan, menunjukkan pembelajaran dengan menggunakan media aplikasi google image pada anak tunarungu kelas XI sangat menarik perhatian siswa. Siswa menjadi aktif dan interaktif dalam mengikuti kegiatan belajar. Minat dan aktifitas siswa tunarungu cukup baik dalam mengikuti pembelajaran sehingga akan dapat mempengaruhi pemahaman materi yang telah disampaikan.

Berdasarkan data hasil observasi penilaian minat dan aktifitas siswa dalam belajar masih rendah, dengan prosentase rerata $60.5 \%$ maka akan mempengaruhi hasil pemahaman materi yang dimiliki siswa. Dari hasil data perbendaharaan kata menunjukkan bahwa nilai rerata kelas 
$62.3 \%$ belum mencapai indikator keberhasilan yang telah ditentukan yaitu $70 \%$, hal ini disebabkan siswa kurang mendapat bimbingan mengenai rincian cara mengakses google image dalam jaringan internet

Dari hasil data yang telah diperoleh bahwa secara umum pada siklus I belum mencapai target ketercapaian tujuan atau standar yang telah ditetapkan. Hal ini mengindikasikan bahwa perlu adanya bimbingan dan penjelasan tambahan saat pembelajaran menggunakan website google image agar dalam siklus berikutnya dapat mencapai hasil yang lebih baik.

\section{Siklus II}

Menurut hasil penelitian yang telah dilakukan di lapangan menunjukkan aktifitas dan minat belajar siswa ada peningkatan, hal ini karena disebabkan guru yang sudah menjelaskan tentang cara mengakses website google image. Sebelumnya anak tunarungu juga mendapat bimbingan dan motivasi terlebih dahulu dari guru. Temuan di kelas menunjukkan penggunaan aplikasi google image menjadi stimulus untuk menumbuhkan sikap aktif siswa, sehingga proses belajar menjadi interaktif. Dengan suasana belajar yang demikian, maka aktifitas dan minat siswa juga mengalami peningkatan yang lebih baik dari pada siklus I.

Berdasarkan nilai rata-rata aktifitas dan minat belajar siswa tunarungu kelas XI pada siklus II rerata kelas mencapai $70.75 \%$ sehingga meningkat $10.25 \%$. Perbendaharaan kata anak tunarungu pada siklus II menunjukkan hasil rata-rata $71.2 \%$ artinya hasil yang telah didapat pada siklus II telah mencapai diatas indikator keberhasilan yang telah ditetapkan yaitu 70, sehingga pelaksanaan tindakan pada siklus II sudah dapat dikatakan berhasil.

Salah satu hasil observasi menjadi sasaran tindakan penelitian adalah dengan berkembangnya kemampuan perbendaharaan anak tuna rungu kelas XI SMALB BCD YPAC Jember sejalan dengan berkembangnya aktivitas siswa. Semakin berkembang kemampuan perbendaharaan kata 
siswa, maka siswa semakin menonjol dalam aktivitas belajarnya.

\section{KESIMPULAN}

Berdasarkan paparan diskusi hasil penelitian, serta berdasarkan hasil data pembahasan hasil penelitian pada bab sebelumnya dimana perbendaharaan kata dengan menggunakan media website google image pada siswa tunarungu kelas XI di SMALB-BCD YPAC Jember pada siklus I mencapai rata-rata kelas $62.3 \%$, pada siklus II rerata kelas mencapai $71.2 \%$ mengalami peningkatan sebesar $8.9 \%$. Sehingga kesimpulannya penggunaan media website google image dapat meningkatkan pemahaman perbendaharaan kata anak tunarungu kelas XI di SMALB-BCD YPAC Jember.

\section{DAFTAR PUSTAKA}

Anton Sukarno. 2006. Pendidikan Anak Tuna Rungu Wicara. FKIP : Universitas Sebelas Maret Press. Surakarta.
Arief S. Sadiman. 2001. Media Pendidikan. Bandung : PT.Remaja Karya.

Arsyad. 2003. Media Pendidikan Dan Penerapannya. Bandung : Remaja Karya.

Budi Susetyo. 2005. Contoh Proposal PTK. Bogor : Diklat Penelitian Tindakan Kelas.

Burhan Nurgiyantoro. 1998. Pembelajaran Bahasa Indonesia I. Jakarta : Balai Pustaka.

Djoko S. Sindu Sakti. 1997. Orthopedagogik Anak Tuna Rungu Wicara. Surakarta:UNS Press.

Gorys Keraf. 1991. Tata Bahasa Indonesia. Jakarta : Balai Pustaka. Haimami

Rasyad, dkk. 1981. Kosakata Bahasa Indonesia. Bandung : Remaja karya. Husain

Parera. 1990. Imbuhan dan Awalan Dalam Bahasa Indonesia. Bandung : Remaja Karya.

Raharjo. 1991. Penerapan Media Pendidikan di Sekolah Dasar. Jakarta : Cipta Karya.

Deni Hardianto. (2012). Media dan Sumber Belajar. Diakses dari http://staff.uny.ac.id/sites/default /file/MEDIA\%20DAN\%20SUM BER520 BELAJAR\%203_0.pdf 
Helper, Vol 35 No 1 (2018) - 53

http://hargaikataku.blogspot.co.id/2013

/06/pengertian-internet.html
https://id.wikipedia.org/wiki/Google_I mages 
Helper, Vol 35 No 1 (2018) - 54

"HELPER" Jurnal Bimbingan dan Konseling FKIP UNIPA 